\title{
Updates on Food Allergy, Increasingly Prevalent Challenge
}

\author{
${ }^{1}$ Tonny Tanus, ${ }^{2}$ Sunny Wangko
}

\author{
${ }^{1}$ Kern Allergy Medical Clinic, Department of Medicine University of California, \\ Los Angeles \\ ${ }^{2}$ Indonesian Anatomists Association \\ Email:drttanus@g.ucla.edu
}

\begin{abstract}
Abstrak: Prevalensi alergi makanan makin meningkat di seluruh dunia dan mengenai semua usia. Keparahan dan kompleksitas penyakit juga meningkat terlebih pada populasi anak. Terdapat beberapa jenis reaksi alergi yang dibahas: immunoglobulin $E$ (IgE) mediated allergies and anaphylaxis, food triggered atopic dermatitis, eosinophilic esophagitis, dan non IgE mediated gastrointestinal food allergic disorders seperti food protein induced enterocolitis syndrome (FPIEs). Tes alergi, baik melalui kulit maupun IgE yang telah dikerjakan sekian lama masih dibebani dengan hasil positif palsu dan negatif palsu yang bermakna dengan manfaat terbatas pada beberapa alergi makanan. Selain menghindari, tidak terdapat terapi yang ampuh untuk alergi makanan. Berbagai imunoterapi telah dipelajari melalui jalur, subkutan, epikutan, oral dan sublingual yang hanya menghasilkan desensitisasi sementara dan dibebani dengan berbagai isu mengenai keamanannya. Agen biologik yang menghambat sitokin/interleukin (IL) dan molekul pada reaksi alergi makanan tampaknya merupakan pilihan yang menjanjikan. Anti IgE telah dipergunakan pada asma dan urtikaria kronis. Anti IL-4 dan IL-13 yang menghambat produksi IgE diindikasikan untuk dermatitis atopik. Anti eosinofil anti IL-5 berhasil menurunkan eksaserbasi asma. Berbagai agen biologik telah dipelajari untuk berbagai kondisi alergik dan imunologik, tetapi efektivitas dan kepraktisan terapi yang mahal ini untuk alergi makanan masih menjadi tanda tanya.
\end{abstract}

Kata kunci: alergi makanan, reaksi alergi, terapi alergi makanan

\begin{abstract}
Food allergies have been increasing in prevalence for years affecting all ages. Disease severity and complexity have also increased, especially in the pediatric population. There are several types of reactions including: immunoglobulin-E (IgE) mediated allergies and anaphylaxis, food-triggered atopic dermatitis, eosinophilic esophagitis, and non IgE mediated gastrointestinal food allergic disorders such as FPIEs. Though allergy testing has been around for years, both skin and IgE testing are burdened by significant false positives and negatives, and are only useful in some food allergies. Avoidance is the sole therapy for food allergy. A variety of immunotherapies have been studied; subcutaneous, epicutaneous, oral, and sublingual. At best they only produce a temporary state of desensitization and have many safety issues. Examples of biologicals which block critical cytokines/interleukins (IL) in allergic conditions are Anti IgE, anti IL-4 and IL-13, and Anti eosinophils, Anti IL-5. Other biologicals are being studied for allergic conditions, but whether these expensive future treatments will be proven effective and practical in food allergy is unknown.
\end{abstract}

Keywords: food allergy, allergic reaction, food allergy therapy

Food allergy is defined as "an adverse health effect arising from a specific immune response that occurs reproducibly on exposure to a given food". This broad definition has been adopted globally. Food allergies are increasing in prevalence throughout the world and now affect $10 \%$ of children and $3 \%$ of adults. ${ }^{2-3}$ Various 
foods have been implicated to produce allergic reactions; the most common offenders are milk, egg, wheat, soy, peanut, tree nuts, fish, shellfish and seeds. They produce several types of allergic reactions such as immunoglobulin E (IgE) mediated, atopic dermatitis (AD) triggered by food, eosinophilic esophagitis (EoE), and non IgE mediated gastrointestinal food allergic disorder.

\section{IgE Mediated Food Allergies}

In this classic phenotype of food allergic reaction, ingestion or contact on inflamed skin leads to crosslinking of food specific IgE on mast cells and basophils. This, in turn, releases mediators manifesting with urticaria, angioedema, bronchospasm, gastrointestinal spasm, hypotension, uterine cramping and, in some cases, anaphylactic shock. The current recommendation is to perform either skin testing, or serum specific $\operatorname{IgE}$ ( $\mathrm{sIgE}$ ) to correlate with the clinical history. The oral challenge, when available, can be done on patients with questionable testing results, either low sIgE or small wheals in the skin prick testing. ${ }^{4}$

Peanut allergy prevalence is approximately $1 \%-3 \%$ in western countries. However, peanut allergy is rarely outgrown and is the leading cause of food related anaphylactic deaths in those countries. Interestingly the Asian populations have a lower prevalence of peanut allergies, but several studies have shown that the children of Asian parents migrating to western countries have increased risk of peanut allergy. ${ }^{1}$

From the LEAP (Learning Early About Peanut) study, early introduction of peanut to children ages 4-11 dramatically reduce the development of peanut allergy. Patients were screened using skin testing and children with prick testing $>5 \mathrm{~mm}$ were presumed to be allergic and excluded from this intervention. International guidelines though have recommended introducing peanut in all infants at the age of 6 months without testing. This may be appropriate in settings where allergy testing is not available, with the anticipation that approximately $2 \%$ of these individuals introduced to peanut will have reactions. Experts have proposed skin testing and/or IgE testing for those high risk patients, and the patients with negative results could be introduced to peanut (Table 1). ${ }^{6}$

More recent data showed the supporting evidence that peanut allergy developed from cutaneous sensitization. One of the strongest risk factor for peanut allergy is severe eczema. The more severe the eczema, the more disrupted the skin barrier, and the higher the levels of peanut in the dust, the higher the risk of peanut allergy. This supports the concept that children became allergic to peanut through the environment. ${ }^{7}$

Ongoing studies on the lower prevalence of peanut allergy in South Asian countries may eventually lead to the overall improvement of global peanut allergy. Hypothesis on vitamin $\mathrm{D}$, theorizing that South Asian patients get more UV radiation and vitamin $\mathrm{D}$ exposure which in turn provide protection against food allergy. The hygiene hypothesis has been studied for years as well, with multiple studies gave evidence that high microbial exposures such as in farming environment protect children against developing allergy.

Table 1. Skin testing and/or IgE testing for high risk patients related to IgE mediated food allergies ${ }^{6}$

\begin{tabular}{lll}
\hline \multicolumn{1}{c}{ Clinical } & Recommendations & $\begin{array}{c}\text { Age of peanut } \\
\text { introduction }\end{array}$ \\
\hline $\begin{array}{l}\text { Severe eczema, } \\
\text { egg allergy or both }\end{array}$ & SPT and/or sIgE, & $4-6$ months \\
$\begin{array}{l}\text { Mild/moderate eczema } \\
\text { No eczema }\end{array}$ & $\begin{array}{l}\text { Introduce peanuts } \\
\text { Introduce peanuts }\end{array}$ & F Family preference \\
\hline
\end{tabular}


Traditional agricultural practice is still quite common in South Asian countries which may modulate the food allergies. Culinary preferences may also influence the antigenicity of peanut, since peanuts are more likely to be boiled or fried in Asian cuisine. These methods produce less allergenic peanuts compared to the commonly roasted peanuts in western diet. $^{3}$ Other factors such as genetic predisposition, gastrointestinal microbiome and high sugar western diet in the development of food allergy have been shown but further confirmatory studies are needed. ${ }^{8}$

Unlike peanut allergy, $90 \%$ of children with wheat, egg, and soy allergies are expected to outgrow their allergy, while $80 \%$ of them with milk allergy outgrow their allergy. ${ }^{9}$ For those who are tolerant of baked milk products, regular home consumption led to tolerance of regular milk (non-baked) in half of the children. Studies have shown that those with higher SIgE numbers or bigger wheals on skin testing larger than $15 \mathrm{~mm}$ tend to have persistent allergies. Other factors associated with persistence include history of severe AD, multiple food allergies, and history of severe anaphylaxis. ${ }^{10}$ Noting that pediatric patients with egg allergy have a strong risk factor for developing asthma, and the risk is similar for both persistent and transient egg allergy. ${ }^{11}$

Patients can also become sensitized through the $\operatorname{IgE}$ mechanism to various foods because of exposure to homologous allergenic pollens. Symptoms are usually localized to the oropharynx hence the name oral allergy syndrome, but systemic reactions have been reported in many of these pollen-food-allergy sensitization. ${ }^{9}$ Common foods include raw apple in patients with birch pollen allergy; melons, banana, and kiwi in ragweed allergy patients; tomato and melon in grass allergic patients. However, many other associations have been reported, some of them listed in Table 2.

Table 2. Pollen Food Allergy Syndrome ${ }^{9}$

\begin{tabular}{lll}
\hline \multicolumn{1}{c}{ Pollens } & \multicolumn{1}{c}{ Family } & \multicolumn{1}{c}{ Cross reactant foods } \\
\hline Birch & Rosacea & $\begin{array}{l}\text { Apple, peach, nectarine, plum, } \\
\text { pear, cherry, apricot } \\
\text { Carrot, celery, coriander, } \\
\text { aniseed }\end{array}$ \\
& Apiaceae & Soy, peanut \\
& Fabaceae & Hazelnut \\
Betulaceae & Walnut \\
Juglandaceae & Cantaloupe, watermelon, \\
Ragweed & Curcurbitaceae & cucumber \\
& Musaceae & Banana \\
& Actinidiaceae & Kiwi \\
Mugwort & Apiaceae & Celery, carrot, aniseed \\
& Solanaceae & Bell pepper \\
& Piperaceae & Black pepper \\
& Brassicaceae & Cauliflower, cabbage, broccoli \\
& Liliaceae & Garlic, onion \\
Cucurbitaceae & Cantaloupe, honeydew, \\
& watermelon \\
& Fabaceae & Peanut \\
& Solanaceae & Tomato
\end{tabular}




\section{Atopic Dermatitis}

Eczema can describe other types of skin condition, but $\mathrm{AD}$ is most often equated with eczema. Pediatric $\mathrm{AD}$ is more common than adult onset $\mathrm{AD}$; only $30 \%$ of all of cases of $\mathrm{AD}$ occur in adult population. Compared to Caucasians, the prevalence of atopic dermatitis is less in Asians, $8 \%$ versus $16 \% .^{12}$ Using the current available and approved testing methods, $33 \%$ of AD patients have food allergy. The most common offending food in these eczema patients is peanut, followed by milk and egg. Besides the usual bothersome symptoms of eczema: itching, dryness, etc., an important issue is that growth of children with $\mathrm{AD}$ can be significantly impaired when there is concomitant food allergy, particularly milk allergy. The importance of a nutritional follow-up on top of the usual medications need to be emphasized. ${ }^{13}$

In addition to inflammatory cytokines and interleukins (IL), Janus kinase (JAK) pathway activation is involved in development of $\mathrm{AD}$. Usual treatments include topical steroids and anti-inflammatory nonsteroidal topical applications, calcineurin inhibitors (TCI): tacrolimus, pimecrolimus, and crisaborole. The clinical perception is that TCI potency is equivalent to mild to moderate topical steroids. ${ }^{14}$

The cytokine inhibitor dupilumab, an anti IL-4 ad IL-13, has recently been approved for AD treatment. Several other IL antibodies are currently in various stages of clinical trials for $\mathrm{AD}$, and JAK inhibitor, baricitinib once a day oral therapy has been granted breakthrough designation for moderate to severe AD who are candidates for systemic therapy. ${ }^{15}$

\section{Eosinophilic Esophagitis (EoE)}

$\mathrm{EoE}$ is a chronic esophageal disease, causing esophageal dysfunction and characterized by histological presence of eosinophilic inflammation. ${ }^{16}$ Food is the primary etiologies, though the role of pollen sensitization may be significant. Even in the absence of nasal symptoms, subclinical untreated inflammation from pollen sensitivities, could lead to impaired esophageal barrier which then lead to more food antigen susceptibility. ${ }^{17}$

The most common food allergens associated with EoE are cow's milk, wheat, egg, soy, nuts and seafood. Initial reports showed approximately $80 \%$ improvement with this six-food elimination diet, but later reports on four-food-group-elimination diet (milk, wheat, egg and soy) showed promising results especially when coupled with topical steroids, either fluticasone inhalerswallow technique or budesonide slurry. A more recent report with a two-food (milk and gluten) elimination diet showed $43 \%$ remission in adults and children with EoE hence the proposal of a step-up elimination diet was recommended. ${ }^{18}$

Little is known about the natural history of EoE. Of the various studies so far, despite being compliant to the established therapies, the rate of clinical tolerance to these food allergens is extremely low. One retrospective analysis showed a somewhat high percentage $(0.5 \%)$ of EoE patients in the tertiary center was able to completely tolerate the foods after an average of 5.4 years of elimination diet. ${ }^{19}$

\section{Food Protein Induced Enterocolitis Syndrome (FPIES)}

FPIES is an non IgE mediated food allergy that is seen in infancy in which children manifest with repetitive emesis, 1 to 4 hours after feeding. Sometimes they present with other clinical features including bloody diarrhea, lethargy, pallor and even dehydration and shock. Cow's milk and soy are the most common triggers, but other foods have been reported. Even typically low allergenic foods have been found to be the culprits such as grains, poultry, vegetables, and legumes. ${ }^{20}$

Though acute presentations are often the case, symptoms can be persistent if not recognized and foods not avoided. Laboratory then can show anemia, hypoalbuminemia, and leukocytosis. Serum IgE and skin testing are usually negative to trigger foods. ${ }^{21}$ 


\section{Diagnosis}

The two most commonly available food allergy testing are the skin prick testing (SPT) and quantification of allergen sIgE measurements. Especially for the immediate type, wheal diameters of SPT have been established and shown to correlate well. $^{22}$ The likelihood of allergy when skin testing is less than $2 \mathrm{~mm}$ is extremely low (Table 3 ).

Table 3. Peanut skin prick test ${ }^{22}$

\begin{tabular}{|c|c|c|}
\hline Size & Risk & Recommendations \\
\hline $0-2 \mathrm{~mm}$ & $\begin{array}{l}\text { Low, 95\% will not have } \\
\text { peanut allergy }\end{array}$ & $\begin{array}{l}\text { Introduce peanut } \\
\text { Oral food challenge }\end{array}$ \\
\hline $3-7 \mathrm{~mm}$ & Moderate to high & $\begin{array}{l}\text { IgE component test } \\
\text { Oral food challenge }\end{array}$ \\
\hline$>7 \mathrm{~mm}$ & High allergy & Avoidance \\
\hline
\end{tabular}

Advance laboratory techniques are becoming more accessible. Component testing, measuring the $\operatorname{sIgE}$ to allergen components such as measuring $\operatorname{IgE}$ antibodies to peanut allergens Ara h1, 2, 3, 8, and 9 can be done by local laboratories. Basophil activation test (BAT) has similar sensitivity to traditional testing, but has superior specificity. This can also be used as a monitor of the clinical resolution of food allergy. The main limitations are the higher cost and lack of access. IgG testing to food allergens remain unproven. Individuals with positive IgG antibodies to foods can have zero symptoms and are virtually healthy. Another test that has been done for years is the flow cytometry measuring the percentage of change in the distribution of white blood cell sizes before and after food challenges in vitro. Unfortunately, the clinical predictive values and specificity are yet to be determined. ${ }^{23}$

Oral food challenge (OFC) is considered the gold standard for confirming a diagnosis of food allergy. It is also used to evaluate the resolution of food allergy either with time or after a successful desensitization. OFC is often done when positive allergy test results were found but history is not clear for clinical reaction. Or vice versa when patients have positive clinical history but SPT and sIgE were both negative. Sometimes OFC is still done despite positive testing and positive clinical history primarily in the settings of milk and egg allergies. It is estimated that up to two thirds of milk and egg allergic patients are actually tolerant of baked products because there are studies showing that regular eating of baked goods actually improve the prognosis, some propose challenging these milk and egg allergic patients who are not already consuming baked goods. ${ }^{24}$

\section{Treatment}

Currently, there is no actual treatment for food allergies. Medications for various manifestations of food allergies, such as anaphylaxis or atopic dermatitis are available. Avoidance is the key in management of food allergy. An oral immunotherapy for peanut allergy is seeking FDA approval in USA for the first ever food allergy treatment. In their study, approximately two third of food allergic patients were able to tolerate $600 \mathrm{mg}$ of peanut, which is equivalent to two peanuts. ${ }^{25}$

Other forms of immunotherapy have been studies as well. ${ }^{1}$ Subcutaneous immunotherapy has not been pursued lately because studies in the 1990's resulted in higher rate of adverse reactions. Sublingual immunotherapy involves applying allergens under the tongue in the form of tablet or drops. Several clinical trials with milk, peanut, tree nuts, and fresh fruits have shown moderate treatment response, with low adverse events compared to oral immunotherapy. Reactions are typically limited to oral pharyngeal pruritus in less 
than $2 \%$ and systemic severe anaphylaxis has not been reported. However, the maintenance doses in sublingual immunetherapy are in mcg-mg, much lower than mg-gm with oral immunotherapy. Oral immunotherapy was found to be more effective than sublingual immunotherapy in achieving desensitization. Epicutaneous immunotherapy, where allergen patch is applied to the back or upper arm has been studied for treatment of peanut and milk allergy. Results have been mixed so far. ${ }^{26}$

Multiple research protocols have studied combination of anti IgE omalizumab with oral immunotherapy. Patients are able to tolerate much higher quantity of allergenic foods with this adjunctive therapy as well as able to reach more rapid desensitization. Eggs, milk and peanut allergy have been desensitized in preliminary studies. Another adjunctive therapy is probiotics. Combining probiotics Lactobacillus with oral immunotherapy is therapeutically effective. Many biologics are in the pipeline as well showing promising results in treating various allergic disorders, including anti IL-5 (mepolizumab and reslizumab), anti IL-5R (benralizumab) in asthma, anti IL4Ra, subunit of IL-4 and IL-13 (dupilumab) in atopic dermatitis, anti IL-13 in EoE; all of which can have roles as adjunctive therapy in food allergy. ${ }^{27,28}$

\section{Conclusion}

The field of food allergy is constantly evolving. Unfortunately, it is still a significant health concern with increasing prevalence worldwide. Progress in testing capabilities is evident, but availability of these advanced laboratory diagnostic testings are lacking. Currently, there is yet an approved food allergy treatment, and the next generation approaches including immunetherapy carry associated risk with debatable efficacies. Adjunctive therapy and biologicals, though, still in beginning stages, may eventually be helpful in food allergy; but the cost could be prohibiting in many circumstances.

\section{References}

1. NIAID - Sponsored Expert Panel, Boyce JA, Assa'ad A,Burks AW, Jones SM, Sampson HA, et al. Guidelines for the diagnosis and management of food allergy in the United States: report of the NIAID-sponsored expert panel. J Allergy Clin Immunol. 2010;126(6 Suppl):S1-S58.

2. Prescott SL, Pawankar R, Allen KJ, Campbell DE, Sinn JKh, Fiocchi A, et al. A global survey of changing patterns of food allergy burden in children. World Allergy Organ J. 2013;6(1):21.

3. Tham EH, Leung DYM. Global perspectives on food allergy: One size doesn't fit all. Ann Allergy Asthma Immunol. 2018; 120(3): 234-6.

4. Nowak-Wegrzyn A, Greenhawt M. The importance of food allergy to the practicing clinician. Ann Allergy Asthma Immunol. 2018;120(3):227-8.

5. Du Toit G, Roberts G, Sayre PH, Bahnson HT, Radulovic S, Santos AF, et al. Randomized trial of peanut consumption in infants at risk for peanut allergy. N Engl J Med. 2015;372:803-13.

6. Tang M, Koplin JJ, Sampson HA. Is skin testing or $\operatorname{sIgE}$ testing necessary before early introduction of peanut for prevention of peanut allergy? J Allergy Clin Immunol Pract. 2018;6(2):408-13.

7. Brough HA, Liu AH, Sicherer S, Makinson K, Douiri A, Brown SJ, et al. Atopic dermatitis increases the effect of exposure to peanut antigen in dust on peanut sensitization and likely peanut allergy. J Allergy Clin Immunol. 2015; 135(1):164-70

8. Scurlock A, Jones SM. Advances in the approach to the patient with food allergy. J Allergy Clin Immunol. 2018, 141(6): 2002-14.

9. Baker MG, Sampson H. Phenotypes and endotypes of food allergy: A path to better understanding the pathogenesis and prognosis of food allergy. Ann Allergy Asthma Immnunol. 2018; 120(3):245-53.

10. Sicherer SH, Sampson HA. Food allergy, a review and update in epidemiology, pathogenesis, diagnosis, prevention, and management. J Allergy Clin Immunol. 2018;141(1):41-58. 
11. Vermeulen EM, Koplin JJ, Dharmage SC, Gurrin LC, Peters RL, McWilliam $\mathbf{V}$, et al. Food allergy is an important risk factor for childhood asthma, irrespective of whether it resolves. J Allergy Clin Immunol. 2018;6:133641.

12. Kaufman B, Alexis A. Presentation of eczema in skin of color. The Dermatologist. 2018;34-5.

13. Jhamnani RD, Levin S, Rasooly M, Stone KD, Milner JD, Nelson $\mathrm{C}$, et al. Impact of food allergy on the growth of children with moderate-severe atopic dermatitis J Allergy Clin Immunol. 2018;141(4):1526-9.

14. Frankel HC, Qureshi AA. Comparative effectiveness of topical calcineurin inhibitors in adult patients with atopic dermatitis. Am J Clin Dermatol 2012; 13(2):113-23.

15. Jones K. American Academy of Dermatology review. Eczema matters summer 2018;20-3.

16. Tanus T. Eosinophilic esophagitis. Brief communication and review of the literature. JBM. 2013;5:190-4.

17. Mahdavinia M, Bishehsari F, Hayat W, Elhassan A, Tobin MC, Ditto AM. Association of eosinophilic esophagitis and food pollen allergy syndrome. Ann Allergy Asthma Immunol. 2017; 118 (1):116-7.

18. Molina-Infante $J$, Arias $A$, Alcedo $J$, Garcia-Romero R, CasabonaFrances S, Prieto Garcia A, et al. Step-up empiric elimination diet for pediatric and adult eosinophilic esophagitis: The 2-4-6 study. J Allergy Clin Immunol 2018;141(4):1365-72.

19. Ruffner M, Brown-Whitehorn TF,Verma R, Cianferoni A, Gober L, Shuker M, et al. Clinical tolerance in eosinophilic esophagitis. J Allergy Clin Immunol Pract. 2018;6(2):661-3.

20. Nowak-Wegrzyn A, Katz Y,Mehr SS, Koletzko S. Non IgE mediated gastrointestinal food allergy. J Allergy Clin
Immunol. 2015;135:1114-24.

21. Nowak-Wegrzyn A, Chehade M, Groetch ME, Spergel JM, Wood RA, Allen

$\mathbf{K}$, et al. International consensus guidelines for the diagnosis and management of food protein-induced enterocolitis syndrome: executive summary-workgroup report of the Adverse Reactions to Foods Committee, American Academy of Allergy Asthma \& Immunology. J Allergy Clin Immunol. 2017;139:1111-26.

22. Togias A, Cooper S, Acebal ML, Assa'ad A, Baker JR Jr, Beck LA, et al. Addendum guidelines for the prevention of peanut allergy in the United States: Report of the National Institute of Allergy and Infectious Diseasessponsored expert panel. Ann Allergy Asthma Immunol. 2017;118(2):16673.e7.

23. Kelso JM. Unproven diagnostic tests for adverse reactions to foods. J Allergy Clin Immunol Pract. 2018;6(2):362-5.

24. MacGinnitie AJ, Young MC. The role of food challenges in clinical practice. $\mathbf{J}$ Allergy Clin Immunol Pract. 2018; 6(2):353-60.

25. Jones SM, Beyer K, Burks AW, Casale TB, O'B Hourihane J, Marcantonio A, et al. Effficacy and safety of AR 101 in peanut allergy: results from a phase 3 , randomized, double blind, placebo controlled trial (PALISADE). J Allergy Clin Immunol. 2108;141(2):AB 400.

26. Gemez Y, Nowak-Wegrzyn A. Immunotherapy for food allergy: are we there yet? J Allergy Clin Immunol Pract. 2017:5:250-72.

27. Schatz M, Sicherer SH, Zeiger RS. The Journal of Allergy and Clinical Immunology: In practice 2017 year in review. J Allergy Clin Immunol Pract. 2018;6:328-352

28. Sampath V, Sindher SB, Zhang W, Nadeau KC. New treatment directions in food allergy. Ann Allergy Asthma Immunol. 2018;120:254-62. 


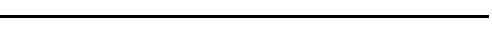

